\title{
The Grand Renaissance Dam and prospects for cooperation on the Eastern Nile
}

Link to publication record in Manchester Research Explorer

\section{Citation for published version (APA):}

Whittington, D., Waterbury, J., \& Jeuland, M. (2014). The Grand Renaissance Dam and prospects for cooperation on the Eastern Nile. Water Policy, 16, 595-608.

\section{Published in:}

Water Policy

\section{Citing this paper}

Please note that where the full-text provided on Manchester Research Explorer is the Author Accepted Manuscript or Proof version this may differ from the final Published version. If citing, it is advised that you check and use the publisher's definitive version.

\section{General rights}

Copyright and moral rights for the publications made accessible in the Research Explorer are retained by the authors and/or other copyright owners and it is a condition of accessing publications that users recognise and abide by the legal requirements associated with these rights.

\section{Takedown policy}

If you believe that this document breaches copyright please refer to the University of Manchester's Takedown Procedures [http://man.ac.uk/04Y6Bo] or contact uml.scholarlycommunications@manchester.ac.uk providing relevant details, so we can investigate your claim.

\section{OPEN ACCESS}




\section{Provided for non-commercial research and educational use only. Not for reproduction or distribution or commercial use.}

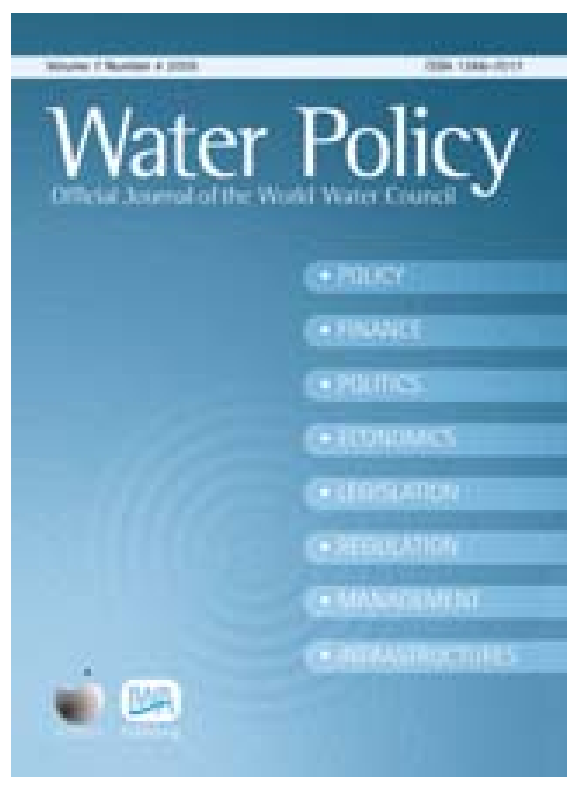

This article was originally published by IWA Publishing. IWA Publishing recognizes the retention of the right by the author(s) to photocopy or make single electronic copies of the paper for their own personal use, including for their own classroom use, or the personal use of colleagues, provided the copies are not offered for sale and are not distributed in a systematic way outside of their employing institution.

Please note that you are not permitted to post the IWA Publishing PDF version of your paper on your own website or your institution's website or repository.

Please direct any queries regarding use or permissions to waterpolicy@iwap.co.uk 


\title{
The Grand Renaissance Dam and prospects for cooperation on the Eastern Nile
}

\author{
Dale Whittington ${ }^{\mathrm{a}}$, John Waterbury ${ }^{\mathrm{b}}$ and Marc Jeuland ${ }^{\mathrm{c}}$ \\ ${ }^{a}$ Corresponding author. Department of Environmental Sciences \& Engineering, Rosenau CB\#7431, School of Public Health, \\ University of North Carolina at Chapel Hill, Chapel Hill, North Carolina 27599-7431, USA and Manchester Business School, \\ Harold Hankins Room 5.18, University of Manchester, Booth Street West, Manchester M15 6PB, UK \\ E-mail: ProfDaleWhittington@gmail.com \\ ${ }^{b}$ New York University, Abu Dhabi, 41 Vandeventer Avenue, Princeton, NJ 08542, USA \\ ${ }^{c}$ Sanford School of Public Policy and Duke Global Health Institute, Duke University, Durham, NC 27708, USA
}

\begin{abstract}
The escalation of tensions between Ethiopia and Egypt over the construction of the Grand Renaissance is at least partly based on a misunderstanding of the nature of the risks this dam poses to Egypt. There is a two-part, win-win deal that can defuse tensions between Egypt and Ethiopia. First, Ethiopia needs to agree with Egypt and Sudan on rules for filling the Grand Renaissance Dam (GRD) reservoir and on operating rules during periods of drought. Second, Egypt needs to acknowledge that Ethiopia has a right to develop its water resources infrastructure for the benefit of its people based on the principle of equitable use, and agree not to block the power trade agreements that Ethiopia needs with Sudan to make the GRD financially viable. Sudan has a big stake in Egyptian-Ethiopian reconciliation over the use of the Nile. Although Sudan's agricultural and hydropower interests now align with those of Ethiopia, there does not seem to be a formal agreement between Ethiopia and Sudan for the sale of hydropower from the GRD. Because the economic feasibility of the GRD and other Ethiopian hydropower projects will depend on such agreements, Sudan has leverage with both Ethiopia and Egypt to encourage this win-win deal.
\end{abstract}

Keywords: 1959 Nile Waters Agreement; Blue Nile Gorge; Climate change; Grand Renaissance Dam; Transboundary cooperation; Nile

\section{Introduction}

Throughout recorded history, Egypt has been the dominant and sometimes the sole significant user of Nile water. Since the pharaohs, it has developed a sophisticated infrastructure for irrigation and flood control. Until the colonial era none of the other peoples or riparian countries in the basin (which today include Sudan, South Sudan, Ethiopia, Uganda, Kenya, Tanzania, Rwanda, Burundi, Central African Republic doi: 10.2166/wp.2014.011 
and Eritrea) had any water resources infrastructure on the Nile, and even now the value of Egyptian infrastructure far exceeds that of all the others. And it is a simple but stark fact that Egypt receives virtually all of its surface water from the Nile and that these Nile flows come entirely from outside its borders. No other Nile riparian exhibits anything close to that level of dependency on the river.

It is on the basis of these facts that Egypt has laid claim to 'acquired rights' to most of the annual flow of the Nile. In most water law regimes, demonstrated use over time has bestowed powerful rights ('first in time, first in right') against which other claims have been futile. Yet in 1997 the International Law Commission completed a draft convention on the non-navigational uses of international watercourses that enshrined the concept of 'equitable use' (United Nations (UN), 1997; McCaffrey \& Sinjela, 1998). This placed historic claims among a number of other factors, including potential use, in determining how water could (and should) be allocated among rival demands. It is to the 1997 Convention that nine of the eleven Nile riparians, including Ethiopia, have turned to undergird their claims to water that would otherwise go to Egypt and Sudan.

In 1959 Egypt and Sudan signed an agreement for 'the full utilization of the Nile' (Republic of the Sudan and the United Arab Republic, 1959). It effectively allocated the entire flow of the Nile between the two countries, with 55.5 billion $\left(10^{9}\right.$ ) cubic meters (bcm) going to Egypt and $18.5 \mathrm{bcm}$ going to Sudan. The agreement was the basis on which Sudan would construct the Roseires Dam on the Blue Nile and Egypt would construct the Aswan High Dam (AHD) on the Main Nile. In 1959 the average annual flow of the Nile as measured at Aswan was estimated to be $84 \mathrm{bcm}$. Netting out the Egyptian and Sudanese shares left $10 \mathrm{bcm}$ for surface evaporation and seepage at the site of the AHD. No water was left over for any other riparians, including Ethiopia which supplies around $83 \%$ of the annual flow of the Main Nile at Dongola (near the upstream end of the AHD reservoir).

The 1959 Nile Waters Agreement became the bedrock for the development of irrigated agriculture and hydropower generation in Egypt and Sudan, but it induced longstanding bitterness and a climate of mistrust among the other eight Nile riparians existing at the time. Egypt and Sudan anticipated that upstream riparians one day would make claims to Nile water, and the 1959 Agreement stipulated that the two countries would negotiate as a team and share any reductions in their shares equally. They also agreed to share equally any natural changes in the annual discharge of the Nile ${ }^{1}$. The 1959 Agreement defined the status quo in the Nile basin for over 50 years and, partly as a result, little additional infrastructure was built on the Nile until quite recently (Figure 1$)^{2}$.

Ethiopia has never accepted the legitimacy of the 1959 Nile Waters Agreement. However, the 1959 Agreement has actually served Ethiopia's long-term interests in one important respect: it explicitly constrained Sudan's water withdrawals to $18.5 \mathrm{bcm}$. Because Sudan has the land resources to expand irrigation and use much more water than the $18.5 \mathrm{bcm}$ (Allan et al., 2013), Ethiopia is better off having Sudan facing a legal constraint on its water withdrawals than a situation in which Sudanese

\footnotetext{
${ }^{1}$ This provision was particularly forward-looking for a water agreement at that time, when hydrological stationarity was widely assumed.

${ }^{2}$ British and Egyptian engineers working in Egypt in the early 20th century developed the Century Storage Scheme for the 'full utilization' of the Nile waters (Waterbury, 1979). The plan included a small dam at Aswan, and upstream control infrastructures in Uganda and Sudan to regulate flows in the White Nile, as well as in Ethiopia and Sudan on the Blue Nile. These projects correspond to the low Aswan Dam (1902), Owen Falls (1954), Gebel el Aulia (1937), Tana (1936) and Sennar (1925), respectively. Shortly after the 1959 agreement, Sudan also developed two new hydropower and irrigation dams at Khasm el Girba in 1964 (Atbara) and Roseires in 1966 (Blue Nile), in order to facilitate use of her 1959 water allocation.
} 


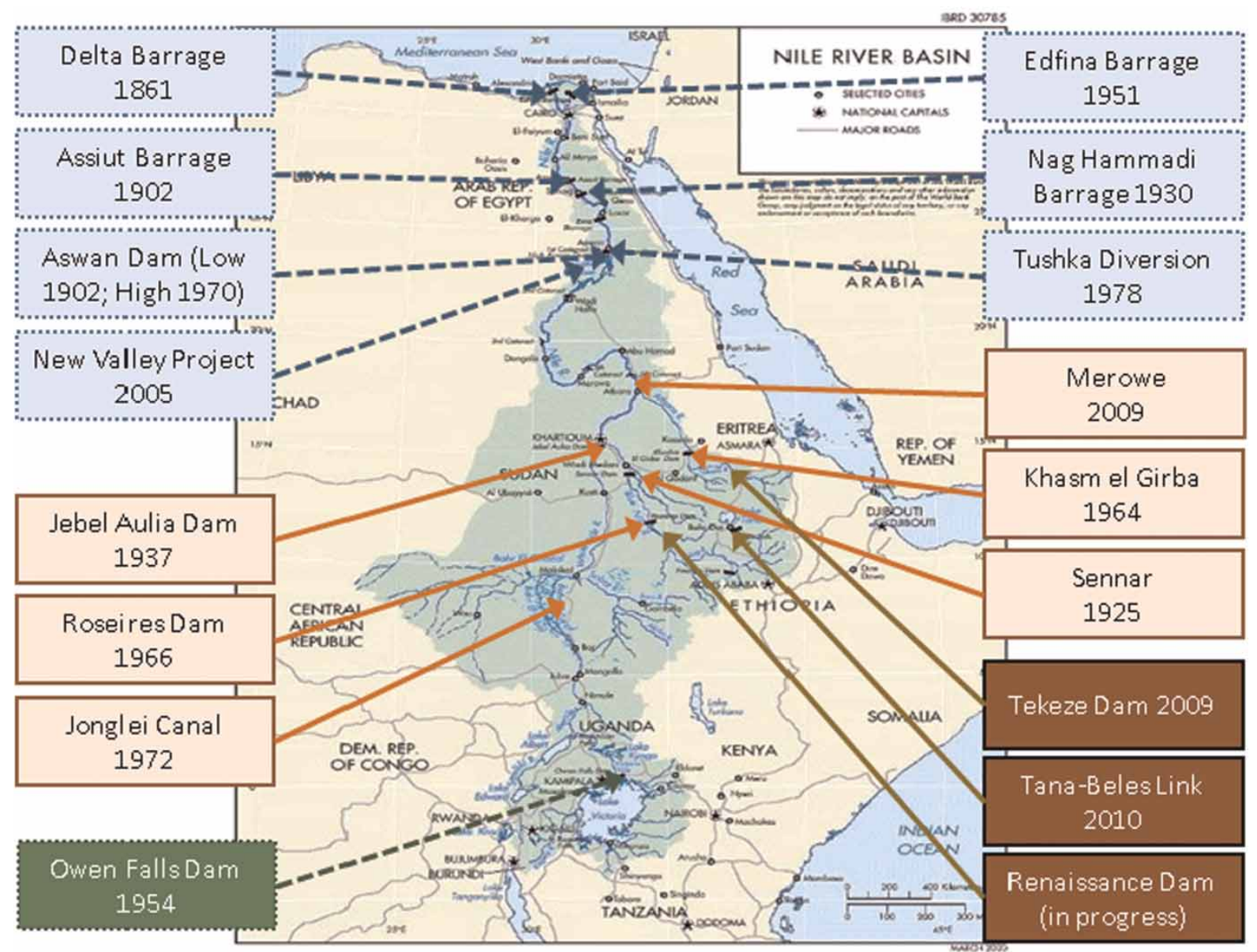

Fig. 1. Existing large water resources infrastructure facilities in the Nile Basin and the Grand Renaissance Dam.

water use was not constrained by international law. By pegging Sudan's water use to 18.5 bcm, the 1959 Agreement makes it harder for Sudan to argue successfully for a substantially larger water allocation based on potential use, and this gives Ethiopia more negotiating room with Egypt and Sudan over its own future claims. A world in which Sudan faced no legal constraints on its water withdrawals would be even tenser than the current situation, and would make finding a cooperative win-win solution even more difficult. This is particularly true because over-year storage facilities built upstream in Ethiopia will allow Sudan to increase its water use beyond this constraint of $18.5 \mathrm{bcm}$. Thus, in the absence of the 1959 Agreement, dam construction in Ethiopia would have posed a more significant threat to cooperation than it currently does.

Although Ethiopia has long claimed a right to use Nile waters, until 2011 there had been no serious challenge to Egypt's historic rights or to the status quo prevailing in the Nile basin that involved the construction of large water storage infrastructure upstream of the AHD. But as Egypt entered into the turmoil of its anti-Mubarak uprising, and as Meles Zenawi, the Prime Minister of Ethiopia, grappled with a fatal illness, Ethiopia announced that it would begin construction of a major multipurpose 
dam on the Blue Nile, near its border with Sudan, called the Grand Renaissance Dam (GRD) (Yahia, 2013) $)^{3}$. With that move, Ethiopia mounted a major challenge to the 1959 Nile Waters Agreement. Over the past few years, both Sudan and Ethiopia have aggressively pursued other new infrastructure projects, including the Merowe Dam (2009), Tekeze (2009) and the Tana-Beles diversion (2010). However, the announcement of the GRD represented a quantum leap in Ethiopia's ambitions.

In relative terms Egypt is economically and militarily the most powerful state in the Nile basin. No other state had felt strong enough to challenge Egypt and the 1959 status quo. However, Ethiopia now believes it has the economic strength to marshal the financial resources needed to proceed unilaterally with the construction of a dam project costing several billion (109) dollars. On July 19, 2010 the Prime Minister of Ethiopia, Meles Zenawi, made this point very clearly to the Egyptian people in an interview on Egyptian television, 'Ethiopia has reached a stage where it can build its own dams with its own money.'

In the past, Ethiopia would have needed financing from international donors to build a major dam on the Blue Nile. Because such water resources investments would have basin-wide consequences, international donors in turn hoped that a basin-wide cooperative framework would be established prior to any financing deal. For over a decade, facilitated by the Nile Basin Initiative, the Nile riparians were engaged in wide-ranging discussions on establishing such a cooperative framework agreement ${ }^{4}$. Seen in this context, the announcement of the GRD was not a surprise nor is it a one-off flash point. Rather it is part and parcel of long-standing structural conflicts between Egypt and the other riparians that stem from power and geographic asymmetries (Cascão, 2009; Waterbury, 2002).

Over the years there has been a tendency for zero-sum analyses of this situation, punctuated by threats and saber-rattling. A recent episode of this came during the tenure of the Mohammed Morsi government in Egypt. Egyptian politicians raised a hue and cry about being deprived of Egypt's lifeblood, and there were calls for military action and destabilization of the Ethiopian polity. In the winter of 2014, after the fall of the Morsi government, Egypt is in a somewhat truculent mood. It portrays itself as in a war against terrorism orchestrated by the Muslim Brotherhood. Its pundits are resorting to nationalist themes that include portraying Ethiopia as deceitful and hostile to Egypt's desperate need for water (Ahmad, 2014; Juwaida, 2014). While we do not believe that military action is likely, the time during which military action to prevent the completion of the GRD remains a feasible option is quickly coming to an end. Any attack on the GRD after it is filled would release a sudden and massive flood into Sudan, Egypt's lone ally in dealing with the other Nile riparians.

\section{Background: dams on the Ethiopian Blue Nile}

The idea of storing Nile waters in the Blue Nile gorge in Ethiopia has been on the minds of the peoples of the Nile basin for centuries (Erlikh, 2002). The river falls rapidly in the narrow canyons of the Blue Nile gorge, offering numerous sites for dams with high heads for hydropower generation and low surface-to-volume ratios, an irresistible combination for dam builders. The Blue Nile also carries much more water than other important Nile tributaries such as the Tekeze-Atbara and the BaroAkobo-Sobat. The United States Bureau of Reclamation (USBR, 1964) developed the first

\footnotetext{
${ }^{3}$ The 'Grand Renaissance Dam' has also been called the 'Millennium Dam', as well as the 'Big Border Dam' (because it is at the site of a smaller proposed dam called the 'Border Dam' near the Ethiopian-Sudanese border).

${ }^{4}$ See http://www.nilebasin.org/newsite/.
} 
comprehensive plans for dams in the Blue Nile gorge more than 50 years ago, and Ethiopian water resources professionals and international consultants have been studying and refining these plans ever since. Over the past decade international consultants working for the Ethiopian Ministry of Water Resources have prepared detailed feasibility studies for several of the most promising dam sites in the Blue Nile gorge in anticipation of a basin-wide cooperative agreement among the riparians that would facilitate requests for international financing. Recent studies suggest that taller dams with more energy production capacity than the original USBR designs are possible at several sites, and these have also identified an additional promising dam site called Beko-Abo (EDF, 2007a, b; Norplan-Norconsult, 2006; Norplan, Norconsult and Shebelle Consulting Engineers, 2007).

In 2009, the discussions among the Nile riparians on establishing a cooperative framework agreement reached an impasse. The riparians agreed on all of the language of the text of a cooperative agreement except for a few crucial words. The draft text of the agreement referred to protecting the water security of all parties. However, Egypt and Sudan wanted a more explicit acknowledgement of their historic rights to Nile water as defined in the 1959 Agreement. The other riparians do not regard the terms of the 1959 Agreement as binding upon them as they were still under colonial control or, for Ethiopia, not consulted by Egypt or Sudan. Negotiations to bridge the gap proved unsuccessful, and by early 2011, six of the upstream riparians - known as the Entebbe Group - had signed the original text of the Cooperative Framework Agreement ${ }^{5}$.

Such was the state of play on January 25, 2011, when tens of thousands of antigovernment protesters occupied Tahrir Square in the heart of Cairo. On February 12 President Mubarak resigned. On February 3, 2011, the Prime Minister of Ethiopia Meles Zenawi announced to the Ethiopian Parliament that his Government had decided to construct the GRD on the Blue Nile near the Ethiopian-Sudanese border.

\section{The GRD: a new water development path for Ethiopia}

As of the fall of 2013, the construction of the GRD was perhaps $25 \%$ complete. Construction will probably require about 10 years, and the expected total cost will exceed US\$5 billion. Table 1 compares several key features of the GRD with the AHD and three other well-known dams in the world (Three Gorges, Itaipu and Nam Theun II). Several aspects of this comparison are noteworthy. First, compared to other large dams on rivers of global importance, the flow at the GRD site is modest. The annual flow of the Yangtse (Chang Jiang) River at the Three Gorges Dam (451 bcm) and the annual flow of the Paraná River at the Itaipu Dam $(368 \mathrm{bcm})$ dwarf the flow of the Blue Nile at the GRD site (48 bcm).

Second, like the AHD on the Main Nile, the storage capacity of the GRD is large relative to the annual flow of the Blue Nile. Both exceed the annual flow of the river, and would thus provide over-year, not just seasonal storage. A cascade of dams in the Blue Nile gorge would completely control the Blue Nile flood, providing both additional hydropower capacity and over-year storage.

Third, the planned installed hydropower capacity at the GRD is more than two and a half times that of the AHD, even though the annual flow is considerably lower. This greater installed capacity at the GRD

\footnotetext{
5 As of October 2013, the Democratic Republic of Congo and South Sudan still have the matter under consideration. Egypt and Sudan have not signed the Agreement and Eritrea remains an observer to the Nile Basin Initiative process.
} 
Table 1. Comparison of GRD with AHD and other hydropower projects of global significance.

\begin{tabular}{|c|c|c|c|c|c|}
\hline Description & $\begin{array}{l}\text { Three Gorges } \\
\text { (China) }\end{array}$ & $\begin{array}{l}\text { Itaipu } \\
\text { (Brazil) }\end{array}$ & $\begin{array}{l}\text { Nam Theun II } \\
\text { (Laos) }\end{array}$ & $\begin{array}{l}\text { AHD } \\
\text { (Egypt) }\end{array}$ & $\begin{array}{l}\text { GRD } \\
\text { (Ethiopia) }\end{array}$ \\
\hline Dam height (m) & 101 & 225 & 39 & 110 & 145 \\
\hline Annual flow (bcm) & 451 & 368 & 8 & $\sim 65$ & 48 \\
\hline Installed capacity (MW) & 22,500 & 14,000 & 1,070 & 2,100 & 5,250 \\
\hline $\begin{array}{l}\text { Gross storage volume } \\
\quad(\mathrm{bcm})\end{array}$ & 39 & 29 & 7 & 153 & 68 \\
\hline People displaced & 1.2 million & 35,000 & 5,000 & 120,000 & $>14,000$ \\
\hline
\end{tabular}

is in part due to the large head available, but it also seems likely that the GRD's power potential has been overestimated. Even so, when completed, the GRD will generate more hydropower than Ethiopia can use in its national grid in the medium term. Ethiopia thus needs an external market for this hydropower for the project to be financially viable ${ }^{6}$. Fourth, in contrast to many large dam projects in other parts of the world, relatively few people live in the areas to be flooded by the GRD.

Table 2 compares the GRD to existing dams on the Nile. As illustrated, the only water storage infrastructure in the Nile basin that is comparable to the GRD is the AHD. The GRD is higher than the AHD and has more installed hydropower capacity, but less storage. When completed, the GRD will be only the second dam on the Nile system capable of providing over-year storage. All of the other dams have much smaller live storage capacities and can only provide seasonal storage ${ }^{7}$.

The GRD will generate multiple types of benefits, but its primary purpose is hydropower generation. About $80 \%$ of the total economic benefits of the GRD will be from hydropower generation. After the reservoir behind the GRD is filled, there will be new evaporation losses (reaching roughly 3 bcm per year), but these will be balanced by reduced evaporation losses from the AHD reservoir, where levels will be lowered because of the short-term reallocation of water storage, and the longer-term increase in evaporation losses upstream in Sudan (where dams will stay at higher levels throughout the year) and Ethiopia (from the GRD). Lower storage in the AHD reservoir means reduced surface evaporation ${ }^{8}$.

Many of the benefits of the GRD actually accrue to Sudan, the immediate downstream riparian. Sudan's seasonal storage dams (Merowe, Roseires and Sennar) will be able to generate more hydropower because of the improved regulation of Blue Nile flows downstream of the GRD, which should allow these dams to operate at higher levels throughout the year. The improved upstream regulation should greatly reduce flood damages in Sudan (especially property losses in Khartoum), which are sometimes severe (Walsh et al., 1994). The GRD will trap the large quantities of sediment flowing from upstream of Sudan (Betrie et al., 2011), saving Sudan the costs of sediment control and removal

\footnotetext{
${ }^{6}$ Although the hydropower potential of a Blue Nile cascade is large, total hydropower production would not approach that of Three Gorges or Itaipu, the world's two largest hydropower dams.

${ }^{7}$ The total storage volume of a reservoir is often conceptualized as having two parts: dead storage and live storage. 'Dead storage' refers to the storage volume below the release intakes of the dam; 'live storage' refers to the volume used to manage the fluctuations in water.

${ }^{8}$ Should they occur, additional irrigation water withdrawals located upstream would also affect these evaporative losses, by decreasing the amount of storage required in the system.
} 
Table 2. Comparison of GRD with existing dams on the Nile.

\begin{tabular}{|c|c|c|c|c|c|c|c|}
\hline Description & AHD & Merowe & $\begin{array}{l}\text { Gebel } \\
\text { Aulia }\end{array}$ & Sennar & $\begin{array}{l}\text { Roseires (after } \\
\text { heightening) }\end{array}$ & $\begin{array}{l}\text { Khasm el } \\
\text { Girba }\end{array}$ & $\begin{array}{l}\text { Renaissance } \\
\text { Dam }\end{array}$ \\
\hline Nile tributary & Main Nile & Main Nile & $\begin{array}{l}\text { White } \\
\text { Nile }\end{array}$ & $\begin{array}{l}\text { Blue } \\
\text { Nile }\end{array}$ & Blue Nile & Atbara & Blue Nile \\
\hline Country & Egypt & Sudan & Sudan & Sudan & Sudan & Sudan & Ethiopia \\
\hline Year completed & 1970 & 2009 & 1937 & 1925 & $\begin{array}{l}1996 \\
2011\end{array}$ & 1964 & $\begin{array}{l}2016 \\
\quad(\text { estimated })\end{array}$ \\
\hline Total storage & $163 \mathrm{bcm}$ & $12.1 \mathrm{bcm}$ & $3.3 \mathrm{bcm}$ & N.A. & $5.5 \mathrm{bcm}$ & $1.3 \mathrm{bcm}$ & $68 \mathrm{bcm}$ \\
\hline $\begin{array}{l}\text { Initial live } \\
\text { storage }\end{array}$ & $137 \mathrm{bcm}$ & $5.7 \mathrm{bcm}$ & $2.8 \mathrm{bcm}$ & $0.9 \mathrm{bcm}$ & $5.4 \mathrm{bcm}$ & $1.2 \mathrm{bcm}$ & $31 \mathrm{bcm}$ \\
\hline $\begin{array}{l}\text { Installed } \\
\text { hydropower }\end{array}$ & 2,100 MW & $1,250 \mathrm{MW}$ & $17 \mathrm{MW}$ & $65 \mathrm{MW}$ & $400 \mathrm{MW}$ & $10 \mathrm{MW}$ & 5,250 MW \\
\hline
\end{tabular}

behind its dams, and in its irrigation schemes. Navigation will be improved on the Main Nile. Because Ethiopia appears to have made a unilateral decision to build and finance the GRD, Sudan is most likely not sharing the costs of constructing the GRD, or paying Ethiopia for these benefits.

The GRD could affect Egypt adversely in three ways. First, if the filling of the reservoir behind the dam were to take place during a sequence of years in which the Blue Nile flow was low and the AHD reservoir itself was low, Egypt might not be able to withdraw sufficient water supplies to meet all of its agricultural needs. The second adverse impact could occur after the GRD is completed. During a sequence of drought years Egypt could run short of water if the operation of the GRD was not carefully coordinated with that of the AHD. Third, Egypt could also be adversely affected by upstream irrigation withdrawals. For example, Sudan could be tempted to increase its irrigation withdrawals because the GRD will provide increased summer low flows.

Nevertheless, it is actually in Egypt's long-term interests for Ethiopia to build not only the GRD, but also additional hydropower dams on the Blue Nile. This is because Ethiopia has a strategic choice between two broad water development paths: (1) a hydropower water development path in which Blue Nile flows are released through a series of hydropower facilities, and (2) an irrigation development path in which water is withdrawn by numerous dispersed irrigation schemes. To the extent that irrigation schemes require water abstractions upstream of hydropower facilities, hydropower production in Ethiopia would be reduced due to lower flow through downstream turbines 9 . The more hydropower facilities on the Blue Nile in Ethiopia, the greater the internal incentive Ethiopia has to direct water to those hydropower facilities rather than use it for irrigation. The GRD is Ethiopia's first big step on a hydropower water development path for the Blue Nile, and Egypt should encourage Ethiopia to choose this option.

\footnotetext{
${ }^{9}$ Irrigation schemes upstream of the GRD would themselves require storage, and thus would be downstream of additional dams in a cascade. These dams could be designed to generate additonal hydropower, but the cascade could generate even more hydropower if new hydropower dams were built upstream of the GRD, and there were no irrigation withdrawals. Also, irrigation schemes downstream of dams in the cascade could lead to lower hydropower production if reservoir release rules were altered to meet demands that do not correspond with power generation needs.
} 


\section{Geopolitical shifts: Sudan and South Sudan}

Sudan is no longer the same country it was when it signed the 1959 Agreement. On July 9, 2011 the southern third of the country was declared the Republic of the South Sudan, with a population of about 8 million and roughly $80 \%$ of the former Sudan's oil reserves. The White Nile flows through the new republic, as do the Baro and Akobo, tributaries to the White Nile that originate in the Ethiopian highlands.

It is not clear to the international community whether South Sudan has any formal agreement with the north regarding its use of the White Nile and tributaries flowing through its territory. Prior to full independence, southern leaders stated that whatever water it might eventually withdraw from these rivers would be within the $18.5 \mathrm{bcm}$ allotted to Sudan in the 1959 Agreement. It is also not clear if the southern leadership sees any advantage to reviving the Jonglei I project, which would partially drain the great seasonal swamps of South Sudan and thereby increase the flow of the main Nile downstream, perhaps by as much as $4 \mathrm{bcm}$ measured at Aswan ${ }^{10}$. Finally, it is not clear whether South Sudan has joined the Entebbe Group that signed the original text of the Cooperative Framework Agreement developed during the multilateral talks facilitated by the Nile Basin Initiative.

If any future water allocation for South Sudan were to be subtracted from the original allocation Sudan received under the 1959 Nile Waters Agreement, this would introduce new complexity into the Nile water allocation problem. South Sudan probably will not be in a situation to utilize significant quantities of Nile water in the near to medium term. In this case it might decide to 'lease' its water allocation to Egypt for a specified period of time. In this case northern Sudan would need to constrain its water withdrawals to $18.5 \mathrm{bcm}$ (measured at Aswan) minus the water allocation South Sudan leased to Egypt. Alternatively South Sudan might decide to lease its water allocation to northern Sudan. In either case Egypt, Sudan and any other parties to the water lease agreement would need to develop an institutional mechanism for verifying that the respective water withdrawals by all parties were limited to the sum of the legal allocations and leased amounts specified in those agreements.

The creation of South Sudan has altered the future of the now-truncated Republic of Sudan in other ways. For nearly two decades Sudan has depended upon the proceeds of oil exports, and Ethiopia has imported about $90 \%$ of its oil needs from Sudan. Going forward it will not be possible for Sudan to rely on oil exports as the motor of its economy to the same extent because of the loss of its major reserves to South Sudan. Beginning in 1999, when an internal re-alignment of the Sudanese government took place, and with added urgency after 2005 as the chances of South Sudan breaking away increased significantly, Sudan began an aggressive pursuit of dam projects, combining its own oil wealth with that of the oil exporters in the Arabian Peninsula. Two big projects were launched and brought to completion. The first was the heightening of the Roseires Dam on the Blue Nile, which provided Sudan with sufficient water supplies during the low-flow summer months to once again irrigate the Gezira Scheme as originally planned, before silt deposition reduced the storage capacity at Sennar and the original Roseires dams $^{11}$. Heightening Roseires also provided irrigation water for additional irrigation development;

\footnotetext{
${ }^{10}$ Upon its independence South Sudan immediately established formal diplomatic relations with Israel. This fueled old fears in Egypt and also in Saudi Arabia that South Sudan might become a stalking horse for Israeli efforts to play Nile politics (Collins, 2002).

${ }^{11}$ Prior to this heightening, Roseires' installed hydropower generation capacity was $280 \mathrm{MW}$. After the heightening is completed, the installed capacity will be about $400 \mathrm{MW}$.
} 
estimates of the new area served are contradictory but range from 380 to 900 thousand hectares of newly irrigated lands (Woertz et al., 2008; Dams Implementation Unit (DIU), 2013).

The second project was the Merowe Dam on the main Nile, with 1,250 MW in generating capacity. Several other new dams located between the confluence of the Atbara and Main Nile and the headwaters of the AHD reservoir are being considered, at sites such as Shereiq, Kajbar and Dal, though it is unclear how such projects will be financed, especially now that northern Sudan no longer has the oil revenues it previously had $^{12}$.

As oil revenues decrease, Sudan may turn once again to its agricultural sector to anchor its economy. Northern Sudan still has great potential - at least in terms of irrigable land area - to expand irrigated agriculture between the Blue and White Nile where its major schemes are already located, as well as upstream on the Blue Nile and Atbara tributaries. The areas between the Blue and White Nile are particularly attractive because there is a natural downward slope from the Blue to the White Nile allowing irrigation water to be delivered by gravity flow. Other new proposed developments, especially sugar plantations, could be supplied with water pumped from the Nile or its tributaries. Yet all the existing plans to develop both new hydropower dams (which would entail evaporative losses) and irrigated areas cannot be fully achieved without northern Sudan exceeding its water allocation in the 1959 Agreement.

\section{Regional stakeholders}

Saudi Arabia, Kuwait and the United Arab Emirates are more than interested by-standers in the Nile arena. All are major importers of agricultural produce and have only modest capacity for domestic agricultural production. Saudi Arabia, the lynch pin of the Gulf Cooperation Council (GCC) has complex regional objectives that may not be fully reconcilable. It has a paramount stake in a stable and friendly Egypt. During the Nasser years it had a stable but hostile Egypt. Only the crushing defeat of the Egyptian armed forces in 1967 at the hands of Israel brought that era to an end.

Because of a long and adversarial history, Saudi Arabia did not welcome an Egypt controlled by the Muslim Brotherhood. It has shored up the 'interim' government that ousted the elected President, Mohammed Morsi, a member of the Muslim Brotherhood. It has opened credit lines worth billions of dollars to the interim government. Saudi Arabia thus has leverage to act as a broker in defusing the current Nile tensions and perhaps one day even to promote broader cooperation.

Simultaneously, Saudi Arabia has looked to Sudan and to Ethiopia as possible sources of agricultural produce, including livestock, to meet rising demand at home and to buffer Saudi Arabia against price shocks in international commodity markets (Cotula, 2009; Woertz, 2013). In that respect Saudi Arabia and other Gulf countries have a stake in agricultural expansion in those countries with the possibility of increased use of Nile water. Such expansion would be viewed with great alarm in Egypt.

Sudan is the swing state in this arena. It has a big stake in Egyptian-Ethiopian reconciliation over the use of the Nile as do Saudi Arabia and the rest of the GCC countries. Yet Sudan has almost never played a proactive role in the Nile basin, generally deferring to Egypt's leadership. That has worked reasonably well for Sudan since the signing of the 1959 Agreement, but may not work so well in the future.

In the current context, Sudan's agricultural and hydropower interests align with those of Ethiopia. Ethiopia needs regional customers for its hydropower, and the greater Khartoum area is the nearest such market.

\footnotetext{
12 The Kajbar and Dal sites are located downstream of Dongola.
} 
Importing hydropower from Ethiopia would allow Sudan to export more of its diminished petroleum production to international markets. At present there seems to be no formal agreement between Ethiopia and Sudan for the sale of hydropower from the GRD. The financial feasibility of the GRD and other Ethiopian hydropower projects will depend on such agreements. This gives Sudan potential leverage with Ethiopia.

To date Sudan has opted to meet its power needs from homegrown projects like Roseires and Merowe, which are much less financially attractive than hydropower dams in Ethiopia. Purchasing hydropower from the GRD would allow Sudan to forgo other less attractive hydropower projects that are currently planned for the Main Nile. Sudan has been reluctant to become dependent on electricity imports from Ethiopia, but it is not difficult to imagine the terms of a sales agreement that would be beneficial to both Sudan and Ethiopia. However, political fears of over-dependence may outweigh financial logic. This works both ways: in 2013 Ethiopia suspended oil imports from Sudan.

The United States also has strong but different interests in the Nile basin. On June 30, 2013, on the occasion of President Obama's visit to a number of African states, the USA announced its Power Africa project, focusing on power development in Africa, and initially involving Ghana, Liberia and Nigeria in West Africa and Ethiopia, Kenya and Tanzania in East Africa. The latter three are Nile basin riparians. They are also members of the East African Power Pool (EAPP), founded in 2005, which includes Egypt and Sudan and most of the upstream Nile riparians. The EAPP aims to establish an integrated power grid for all of East Africa. Ethiopia clearly would be the single largest source of supply to that grid.

\section{Factoring in climate change}

Climate change could also create new challenges for the Nile riparians as they think through their strategic options regarding future water development paths and the pros and cons of more (or less) cooperation with their neighbors. There are three major consequences of climate change that should concern Nile decision makers: higher temperatures, increasing uncertainty over Nile hydrology and sea level rise. Although no one knows precisely how climate change will affect the Nile basin in the future, some of the consequences of these three direct effects are much clearer than others.

First, there is general agreement that climate change will gradually increase temperatures throughout the basin (Intergovernmental Panel on Climate Change (IPCC), 2007). Higher temperatures will increase evaporation rates from existing and new reservoirs, leaving less water available in storage for agricultural, industrial and municipal use. Simply adding more storage capacity to the system will not generally increase the total water available for consumptive uses because there is already more storage in the system than the annual flow of the river. Shifting storage upstream, however, will provide net water savings due to lower evaporation losses from the GRD relative to the AHD, and these savings will likely become increasingly valuable as temperatures rise. Higher temperatures also could increase beyond the optimal growing range of some crops, leading to reduced yields and even crop failures, and will certainly increase crop water requirements (Lobell et al., 2011). An increase of $3^{\circ} \mathrm{C}$ (corresponding to what most models forecast for the next 50-100 years) will increase crop water requirements for the existing crop mix in the basin by approximately 10\% (Jeuland, 2009). Higher temperatures will also increase household water use. All three of these effects (increased evaporation, crop water use and household water use) will tighten the balance of water supply and demand throughout the Nile basin.

Second, there is great uncertainty associated with projections of the effects of climate change on precipitation and surface water flows in the Nile basin (Conway, 2005; Elshamy et al., 2009). Some models 
forecast increased precipitation and runoff, while others forecast reduced precipitation and runoff. The bottom-line for Nile decision makers is that uncertainty has increased, and they can no longer expect that water availability will remain as it was in the past (Jeuland, 2010). This means that options to adapt to unexpected future changes become increasingly valuable (Jeuland \& Whittington, 2014). Cooperation expands the set of these options because it acts as a form of insurance whereby risks can be shared among riparians (Blackmore \& Whittington, 2008). In addition, if Nile riparians cooperate, storage infrastructure that allows for coordinated responses to downstream water demands will increase the range of potential adaptation options to hydrological changes.

Somewhat counter intuitively, more storage (i.e., dams) is not necessarily the proper adaptation to increasing hydrological uncertainty. More storage would help if the only consequence of climate change were to increase the variability of hydrological flows. However, if climate change leads to lower average flows, which some models suggest may occur, it is quite possible to make the mistake of overinvesting in storage capacity that will not be needed (Jeuland \& Whittington, 2014). In other words, the Nile riparians may build more storage capacity than they can use efficiently, which would represent a waste of scarce financial resources. However, the Nile carries large sediment loads that diminish the long-term storage capacity of reservoirs. Additional storage capacity is valuable for sediment storage because it extends the economic life of existing downstream dams.

Third, the Nile Delta is at risk from sea level rise due to climate change; indeed, it is one of the most vulnerable river deltas in the world. About half of Egypt's population lives in the Nile Delta, which includes major cities such as Alexandria, Tanta, Mansoura, Mahalla al Kubra, Benha, Zagazig and Damietta. Although unlikely, a 5-m sea level rise would entail catastrophic loss of agricultural land in the Nile Delta and require massive population resettlement or huge investment in protective infrastructure.

At first glance a loss of substantial portions of the Nile Delta to sea level rise would seem to be Egypt's problem, with few implications for upstream riparians. However, such a large change in land and water use in Egypt would have ramifications throughout the Nile basin. A major portion of Egypt's historic water use would no longer be needed in the Nile Delta. How would this newly 'freed up water' be used? Egypt could decide to reclaim new lands. Alternatively, it could concentrate on non-agricultural sectors of its economy, in which case it would have water to lease or sell to upstream riparians, or to initiate joint agricultural ventures in Sudan with its displaced farmers. Also, upstream riparians might challenge Egypt's historic use rights if it lost much of the cultivated lands in the Nile Delta on the grounds that this water was no longer needed or being used for its original purpose.

Unilateral responses by Nile riparians to the consequences of increasing temperatures, changing hydrology and sea level rise will almost certainly be both economically inefficient and politically risky. Because adaptation to climate change is also likely to be expensive, the Nile riparians need the benefits of cooperative trade agreements and more integrated markets to finance effective adaptation measures. The prospect of climate change thus enhances the value to Nile riparians of finding a cooperative water development path, and increases the incentives for Nile riparians to reach cooperative water management agreements. Third parties will probably try to increase these incentives ${ }^{13}$. Nonetheless, there are no guarantees that cooperation on climate change adaptation will in fact occur.

\footnotetext{
${ }^{13}$ It is important to note, however, that one of these potential third parties, Saudi Arabia, has a track record of skepticism on the threat of climate change and the dangers of reliance on fossil fuels.
} 


\section{Concluding remarks: finding common ground on the GRD}

The sources of the conflict over Nile waters are old and cannot be dealt with merely through short-term agreements specific to the GRD. But the escalation of tensions between Ethiopia and Egypt over the construction of the GRD is at least partly based on a misunderstanding of the nature of the risks this dam poses to Egypt. The GRD does not spell disaster for the downstream riparians because hydropower generation is largely a non-consumptive water use. After the GRD is filled, the dam itself will not appreciably reduce the total water supply available to Egypt and Sudan.

There is a win-win deal that can defuse tensions between Egypt and Ethiopia over the GRD. First, Ethiopia needs to agree with Egypt and Sudan on rules for filling the GRD reservoir and on operating rules for the GRD during periods of drought. Second, Egypt needs to acknowledge that Ethiopia has a right to develop its water resources infrastructure for the benefit of its people based on the principle of equitable use, and agree not to block the power trade agreements that Ethiopia needs with Sudan. Because the economic feasibility of the GRD and other Ethiopian hydropower projects will depend on such agreements, Sudan has leverage with both Ethiopia and Egypt to encourage this win-win deal.

A broader cooperative framework for use of the Nile would require some accommodation on the part of both Egypt and Ethiopia, but it need not cause 'appreciable' harm to either. The combined efforts of Saudi Arabia and the GCC more generally, Sudan and the United States may be required to encourage Egypt and Ethiopia toward a shared vision and cooperative framework. We recognize that the default position in the Nile basin, as elsewhere, is to seek self-sufficiency at the expense of cooperation, but participation by the Nile riparians in the Nile Basin Initiative (NBI) showed at least some willingness on their part to move beyond that kind of thinking. The failure of the NBI also shows the challenges that the riparians are likely to continue to encounter.

If Egypt acknowledges the legitimacy of the equitable use criterion for Ethiopia, this may have implications for upper basin riparians on the White Nile. In the long run the creation of regional water markets may permit more flexibility in water allocations, allowing limited water supplies to move to the highest value uses. But given the present dispute over the GRD, the trust required for regional water markets to function seems far away.

Even without any change in the 1959 Agreement and without any concessions by Egypt and Sudan to the other nine upstream riparians, Egypt will need to make major adjustments in its current use of water. This is because its current use of Nile water is based on two 'windfalls'. The first is the unused portion of Sudan's share under the 1959 Agreement, which has recently been on the order of $5 \mathrm{bcm}$ per year. The second is that the average annual flow of the Nile has been above the $84 \mathrm{bcm}$ assumed in the 1959 Agreement, and this long-term mean has not been adjusted as the provisions of the 1959 Agreement require. It is likely that Sudan will use its full share within a decade. As global warming increases evaporation losses and crop water requirements, and possibly also reduces the average discharge of the Nile, supplies will tighten further. Taken together, these changes mean that Egypt will likely have to get along with less water in the future. Egypt's experience in the past few decades indicates that it is capable of engineering much greater water efficiency through reductions in physical losses, re-utilization of drainage and municipal water, and less waste in on-field irrigation. 


\section{Acknowledgments}

The authors are grateful to Alan Bates and J. A. Allan for their comments on a previous draft of this paper.

\section{References}

Ahmad, M. M. (2014). Ethiopia's Deceitful Pretexts. al Ahram, Cairo.

Allan, J. A., Keulertz, M., Sojamo, S. \& Warner, J. eds. (2013). Handbook of Land and Water Grabs in Africa: Foreign Direct Investment and Food and Water Security. Routledge International Handbook. Routledge, Abingdon, UK.

Betrie, G. D., Mohamed, Y. A., van Griensven, A. \& Srinivasan, R. (2011). Sediment management modelling in the Blue Nile Basin using SWAT model. Hydrology and Earth System Sciences 15(3), 807-818.

Blackmore, D. \& Whittington, D. (2008). Opportunities for Cooperative Water Resources Development on the Eastern Nile: Risks and Rewards. An Independent Report of the Scoping Study Team to the Eastern Nile Council of Ministers. World Bank, Washington, DC, 102 pp.

Cascão, A. E. (2009). Changing power relations in the Nile River Basin: Unilateralism vs. cooperation. Water Alternatives 2(2), 245-268.

Collins, R. O. (2002). The Nile. Yale University Press, New Haven, CT.

Conway, D. (2005). From headwater tributaries to international river: observing and adapting to climate variability and change in the Nile basin. Global Environmental Change 15(2), 99-114.

Cotula, L. (2009). Land Grab or Development Opportunity? Agricultural Investment and International Land Deals in Africa. Iied, London, UK.

DIU, Dams Implementation Unit, Sudan (2013). The Heightening Project. Dams Implementation Unit, Sudan. http://www.diu. gov.sd/en/roseires.htm, accessed October 1, 2013.

EDF (2007a). Pre-Feasibility Study of Border Hydropower Project, Ethiopia. Draft Final Report. Edited by Eastern Nile Power Trade Program Study, ENTRO, Addis Ababa.

EDF (2007b). Pre-Feasibility Study of Mandaya Hydropower Project, Ethiopia. Final Report. ENTRO, Addis Ababa.

Elshamy, M. E., Seierstad, I. A. \& Sorteberg, A. (2009). Impacts of climate change on Blue Nile flows using bias-corrected GCM scenarios. Hydrology and Earth System Sciences 13(5), 551-565.

Erlikh, H. (2002). The Cross and the River: Ethiopia, Egypt, and the Nile. Lynne Rienner Publishers, Boulder, CO.

IPCC (2007). Climate Change 2007: The Physical Basis of Climate Change. Contribution of Working Group I to the Fourth Assessment Report of the Intergovernmental Panel on Climate Change. Cambridge University Press, Cambridge, UK.

Jeuland, M. (2009). Planning Water Resources Development in an Uncertain Climate Future: A Hydro-economic Simulation Framework Applied to the Case of the Blue Nile. Environmental Sciences and Engineering, University of North Carolina at Chapel Hill, Chapel Hill, NC.

Jeuland, M. (2010). Economic implications of climate change for infrastructure planning in transboundary water systems: an example from the Blue Nile. Water Resources Research 46(11), W11556, doi:10.1029/2010WR009428, 2010.

Jeuland, M. \& Whittington, D. (2014). Water resources planning under climate change: Assessing the robustness of real options for the Blue Nile. Water Resources Research 50, doi: 10.1002/2013WR013705.

Juwaida, F. (2014). The Arab League and the Renaissance Dam. al Ahram, Cairo.

Lobell, D. B., Schlenker, W. \& Costa-Roberts, J. (2011). Climate trends and global crop production since 1980. Science 333(6042), 616-620.

McCaffrey, S. C. \& Sinjela, M. (1998). The 1997 United Nations Convention on International Watercourses. The American Journal of International Law 92(1), 97-107.

Norplan-Norconsult (2006). Karadobi Multipurpose Project Pre-Feasibility Study. Draft Final Report. Ministry of Water Resources, Federal Democratic Republic of Ethiopia.

Norplan, Norconsult and Shebelle Consulting Engineers (2007). Beko-Abo Multipurpose Project Reconnaissance Study Report. The Ministry of Water Resources, Federal Democratic Republic of Ethiopia, Addis Ababa. 
Republic of the Sudan and the United Arab Republic (1959). United Arab Republic and Sudan Agreement For The Full Utilization of the Nile Waters. In 6519 UNTS 63, Cairo.

United Nations (1997). Convention on the Law of the Non-Navigational Uses of International Watercourses. In A/51/869, United Nations.

USBR (1964). Land and Water Resources of the Blue Nile Basin. Main Report and Appendices I-V. United States Department of Interior, US Government Printing Office, Washington, DC.

Walsh, R. P. D., Davies, H. R. J. \& Musa, S. B. (1994). Flood frequency and impacts at Khartoum since the early nineteenth century. Geographical Journal 160(3), 266-279.

Waterbury, J. (1979). Hydropolitics of the Nile Valley. Syracuse University Press, Syracuse, NY.

Waterbury, J. (2002). The Nile Basin: National Determinants of Collective Action. Yale University, New Haven, CT.

Woertz, E. (2013). Oil for Food: the Global Crisis and the Middle East. Oxford University Press, New York, NY, 319 pp.

Woertz, E., Pradhan, S., Biberovic, N. \& Koch, C. (2008). Food Inflation in the GCC Countries. Gulf Research Center, Dubai.

Yahia, M. (2013). Leaked report sparks disagreement between Egypt and Ethiopia over dam. Nature Middle East, doi:10.1038/ nmiddleeast.2013.99.

Received 7 January 2014; accepted in revised form 12 February 2014. Available online 8 March 2014 